\title{
Imagination in LIS research
}

\author{
Paul Sturges
}

\begin{abstract}
The quality of research in information science and library science is criticized. Researchers are encouraged to use their imagination, empathy and lateral thinking skills. Choice of topic, use of existing theories and theoretical models, literature searching, application of methods and methodologies, and appraisal of results are all areas in which imagination can be used productively. Several published studies are discussed briefly by way of example.
\end{abstract}

The true sign of intelligence is not knowledge but imagination

-Albert Einstein.

\section{Introduction}

It is my contention that much of LIS research at all levels, throughout the world, is dull, formulaic and often disgracefully bad. We need to change this by aiming towards a discipline with research that is lively, relevant, accomplished and above all intelligent. I suggest here that intelligent research must always be driven by the imagination rather than mere hard work or the following of a set of rules obtained from a textbook on research technique. Imagination is a good word to describe what is needed because it is not too specific, but it does convey a strong sense of openness and unpredictability. Looking at examples of the way the word has been used in the past, we can find it describing what also might otherwise be called insight, empathy, or instinctive moral understanding. Lateral thinking is also a term that indicates much the same as imagination. Imagination is about letting the mind make connections, exploring what seem at first to be unlikely possibilities, and cultivating a willingness to stretch and even break other people's rules.

\section{Author \\ Paul Sturges is Professor Emeritus in the Department of Information Science at Loughborough University. He is also a member of the Editorial Advisory Board of the Journal of Documentation.}

Email: r.p.sturges@lboro.ac.uk 
Obviously anyone looking here for a rigorous definition of the term is going to be disappointed.

The thoughts which follow are based on the experience of reading hundreds of draft and completed undergraduate, master's and doctoral dissertations as either supervisor or examiner, and large numbers of papers submitted for possible publication in journals, in addition to the usual scanning and reading of the published LIS literature that is to be expected of an active academic. Most of the material on which the following generalisations are based, originated in individual projects for academic and professional qualifications, but reports and articles based on commissioned research are not completely exempt from the strictures offered here. Much of the material was British, but a very substantial proportion came from the developing world and some from Europe. Standards in the (mainly published) material that one reads from North America are very much higher, but often by means of such a slavish respect for rules and conventions that excellent work is sadly predictable. The almost universal lack of inspiration is depressing for a supervisor, but at least there is the chance to offer remedies while the work is in progress. On the other hand, the examiner, the reviewer and the reader of published material are presented with what claims to be a finished product, and there is either no scope for helpful intervention, or only a limited opportunity with unpublished material via the mediation of an editor. Are there examples of work that does not deserve these strictures? Yes, of course there are. Journal of Documentation, for instance, consistently publishes an exciting mix of material with many different approaches to LIS. It is not that there is no good material; rather there is so much that is bad or indifferent.

All this is unfortunate if you look at it from the perspective of a researcher but, given that LIS is a practical discipline, it is something of a professional disaster. The great virtue of LIS research is that first it deals with issues that are both fundamental (how human beings interface with information of all kinds) and immediate and urgent (the effectiveness of technologies and systems). Its second strength is that the LIS research literature addresses communities of practitioners - people who look to it for guidance in their professional lives. LIS researchers can make a difference much more than can their fellow researchers in predominantly academic disciplines. What will be offered here are a few personal thoughts on some areas in which LIS is arguably deficient: identifying topics for research, the role of theory, working with the literature, the choice and application of methods, and the interpretation of findings. These thoughts will be illustrated mainly, but not entirely, from personal experience.

\section{Topics}

Calling for imagination in choice of topics may seem pointless if you need a research contract of some kind so as to survive, or your employer has funded you to take a degree with a research topic already chosen for you. A topic provided for you is rather like an arranged marriage. It can work out well and love can develop, but it does not really compare with the excitements of a marriage for love. The good thing is that if you are in an arranged research relationship, a little love on the side is not socially condemned: so why not carry out a small personal project 
in your spare time? If you do have the chance to choose, it is important not to waste the chance to use some imagination. Sadly, students choosing a dissertation topic are frighteningly conventional. All too frequently they come to a potential supervisor saying something like 'I want to research student responses to a particular service or technology and I want to use a questionnaire'. Fellow students form an easily accessible community, response to an existing service is nice and specific, and everyone does a questionnaire, don't they?

This disappointing lack of ambition must be replaced by something more imaginative, but that can be scary. For example, a student who had been persuaded to choose an analysis of information services for visitors to heritage sites (brochures, guidebooks, audio tapes, signage, information desks, room attendants, etc.) almost abandoned the topic because 'There is nothing written about it'. Of course there was something written, but not much and nothing in the LIS literature. What a lucky student to find a topic that had not already been trampled all over! If there is any possibility of choice, a potential researcher should ask him- or herself: 'Is there a question I really want to answer?' Interrogating one's reading, observation and conversations for questions that need an answer will yield something to all but the most incurious. And someone so incurious probably ought to forget about research.

In recent years my own interest has turned towards questions about the psychology of learning. These caught my attention when a colleague who had previously taught in a department of education, developing potential teachers, joined the LIS department. Looking at what she taught and her range of knowledge, it occurred to me that the LIS community tended to take learning as a given, and did not question how it worked or what implications that might have for information services. Looked at in the light of the psychology of learning, the bland assumption that people want information and that this drives the need to provide ever more comprehensive and sophisticated services began to seem a little inadequate. So where to turn so as to develop this topic further? The twentieth century literature of pedagogy in which Piaget and Montessori are iconic names offers some very interesting answers, but that is not the only potential area with relevant content.

Anyone who scans the reviews of books in the quality newspaper press may well have noticed that in the last decade there has been a flow of titles introducing neuroscience to a popular audience, for example Rose (2006), Ramachandran (2004), Winston (2003) and many more. A fascinatingly relevant line of argument can then be developed from this. It begins with the simple observation that babies and young children learn at amazing speed from their own exploration and experimentation with the world around them. The measurement of brain activity allows measurement of this and reveals that the brain actually develops in response to these flows of information. This is best illustrated by evidence from cases of injuries in which victims have suffered the physical loss of brain tissue. The functions that had been performed by the damaged areas can be re-learned by other parts of the brain. The broad significance of this for information science ought to be obvious, but the specific ways in which it might be explored to improve understanding of the users of information is less clear. In fact at the time 
of writing this I am exploring questions as what one can learn about the intellectual processes involved in intentional learning, and information seeking, from knowledge of specific aspects of brain function. It could be an imaginative step too far, but it is a risk that I feel driven to take.

\section{Theory}

Theory is a delicate subject. Those who remember the days of the Soviet system in Russia and Eastern Europe will perhaps recall the pre-1990 presentations and publications by colleagues from those parts of the world that were weighed down with dreary (and unimaginative) Marxist-Leninist thought. The actual research content or attempts at originality could usually be found cowering somewhere in the last third of the paper. This tyranny of theory did not entirely die with the coming of perestroika, and rather subtler versions of it can be found in work from the People's Republic of China and some rigidly Islamic countries, with even a suspicion of the same thing from intellectual outposts such as Mormon universities in Utah. Theory is about clearer and more explicit thinking rather than this largely enforced subjection to a set of ideas.

There is, however, something that could be regarded as a problem here. Researchers who have identified an appropriate theoretical position do not necessarily stop at clarity regarding basic concepts and their relation to each other. There is a temptation to turn to some prominent philosopher who offers a critique and a set of answers that can be put to use in the case at hand, and with whom a satisfying intellectual wrestle can be had. Jurgen Habermas (1991) is frequently turned to: I have found him helpful myself. There is a danger in this. The philosophising is seductive and articles from Scandinavian and German colleagues can often contain more arcane argumentation than actual reporting of investigations and practical findings. A colleague of mine who took his Ph.D. at a continental university was directly told to curb his English empiricism and get his theory, with due attention to relevant philosophers, sorted out before he could be cleared to get down to business. The desire for clear thinking is admirable: but the devotion to theory as such is more questionable. It can lead at its worst to the adoption of a language and terminology that is so gratuitously obscure as to defy comprehension. Unfortunately, there is more than one LIS academic who is victim of this tendency.

Maybe the first piece of advice one can offer here seems to cut against the theme of this article and it is this: Keep your feet on the ground. Sort out your concepts, decide how you are going to describe them and write about them in a way that a readership of practitioners as well as academics should be able to understand. Where imagination comes in is when something is sufficiently novel and complex that everyday language and simple concepts will not immediately do it justice. This is where modelling your ideas can come into its own. As a non-modeller I was agreeably surprised some years ago to find a set of ideas that I needed to marshal forming themselves, as if of their own accord, into a kind of descriptive matrix. I was trying to say something about the information aspects of the African national liberation struggles and post-colonial conflicts: itself a topic sufficiently off the wall as to be (politely) described as an imaginative choice. The model 
itself provided the focus for an article (Sturges, 2004) and acted as the basis for studies of SWAPO in Namibia and The Lord's Resistance Army in Uganda. There was some helpful theory in the literature, but essentially the theoretical aspects of my studies had to be part of my own input - the model in fact.

\section{Literature}

Our dealings with the literature require imagination precisely because the LIS literature has the limitations set out in the introduction. The potential of LIS to lead us into unexpected places is enormous, but the literature shows that most writers in the field have stayed in safe places. If we want to make progress with valid, but previously unexplored, topics we need to think imaginatively about what to read. An example will illustrate the point. It arose when in the mid-1990s I had the opportunity to look at information seeking and use in rural Malawi. (Sturges and Chimseu, 1996) Going out along the bumpy red laterite roads and conducting focus groups with villagers and interviews with agricultural extension workers (in partnership with a resourceful young colleague George Chimseu who did the hard work in Chichewa the national language) was a deeply affecting experience. The fascinating information and insights the respondents so freely gave us formed a very worthwhile data set, but to put them in context was far from easy. A conventional search of the literature suggested that hardly anyone had previously conducted LIS research with the African rural population. It is stretching a point to say that there had been nearly ten relevant studies.

Revealingly, a study of adult education in rural Africa (Amaratunga and Shute, 1982) was much more helpful. The rather contingent discovery of this article raised the question as to whether there might not be more useful material from outside the LIS literature. The answer was definitely 'Yes'. One or two official reports from Malawi and neighbouring Zambia were traced, along with articles in journals such as Human Organisation, Agricultural Administration and Extension, and the Journal of Extension Systems. Best of all was a yellowing typescript completely devoid of bibliographical details, other than a 1982 date, on communication of innovation amongst Zimbabwean farmers. This turned up in a box file in the now sadly defunct Overseas Development Institute Library in London. The clue provided by this identification of studies outside the LIS literature was pursued in later work on the African rural information environment for a book with broader coverage (Sturges and Neill, 1998). Articles published in the literature of Agricultural Science, or Development Studies, if read for their information significance proved both informative and thought provoking. I had never intended to read about alley cropping for mulch and fuel, the marketing of fomented milk products, or the role of spirit mediums in selecting planting and harvesting times. When I did, I learned much more about African rural information and communication than I ever did from the LIS literature. Only a little willingness to read unconventionally was required. 


\section{Methods}

On imagination in methods there is much to be said, but for the purposes of this article it is more or less enough to refer to my previous article in LIR (Sturges, 2008). This rejects the slavery of LIS research to the questionnaire survey $-\mathrm{a}$ slavery much greater in extent than the published part of the literature reveals. Surveys generally tell you what you wanted to be told in the first place; and you can use statistical tests of significance to 'prove' that what you have been told is true. Dressed up with plenty of tables and charts generated by your database software, you have what seems to be the ideal LIS article. In fact most such articles are either nonsense or too banal to be worth publication. I suggested then that imaginative choice and, indeed, invention and reinvention of methods is so much more appropriate.

Some new research seems to show that my previous article was not as a voice of one crying in the wilderness. An as yet unpublished Lithuanian study makes a lively assault on the question of what children feel about libraries. This is, in fact, a topic that would lend itself to a questionnaire survey, and even better to an interview or focus group programme. However, the researchers have made opportunistic use of a large set of posters about libraries created by Lithuanian children for a competition in 2010. In effect they have had the imagination to ask what children say when asked to use their own imagination. The posters are systematically analysed for the narrative 'text' that can be teased out from the pictures, captions and slogans. The researchers then identify fabula and stereotypes that the children adopt or create, and the context that they indicate. The researchers look for recurring forms of story and stereotypes that seem to typify the children's perceptions. It is a pleasing study, working imaginatively with some delightful raw 'data'.

\section{Findings}

There is also much to be said in favour of imagination in the way in which LIS research deals with findings and draws conclusions. All too often a study that presents interesting data is merely topped off with a recapitulation of the most interesting findings. This is obviously not enough. Research is not about identifying what is interesting, it is about discovering what is significant and explaining why. The two most demanding stages of any research project are the initial one in which the topic is defined and research methods selected; and the final one in which hard thought has to be applied to what has emerged from the findings of the study so to draw worthwhile conclusions. At the final stage there seems to be a loss of energy or (very probably) a shortage of time. Dissertations and theses, as well as commissioned research, all operate within a specified time frame. Submission dates or the end of funding seem to come all too soon. Hardly anyone allows sufficient time to think about the results and to apply a little imagination to their interpretation. Even the private research of salaried academics is rushed forward by the need to show a good annual publication record. This is potentially disastrous. 
Some work of my own that I would claim shows imagination, at least in its genesis, suffered from this need for momentum. In 2005, the publication of some cartoons about the prophet Mohammed in a Danish newspaper sparked riots, destruction of property and some violent deaths in several locations. Librarians had reason to fear the consequences of holding copies of this newspaper, or other allegedly offensive material so the IFLA Freedom of Access to Information and Freedom of Expression (FAIFE) Committee of which I was then Chair was asked to look into the question. We organised a very successful plenary debate at the IFLA Conference in Seoul, South Korea in 2006 and I expanded my opening remarks into an article (Sturges, 2006). In looking at the problem of the giving and taking of offence, I sought guidance or inspiration from areas outside librarianship and happened on the practice of comedy. The paragraphs on comedy and offence were an imaginative step in terms of the LIS literature, and it occurred to me that this could usefully be taken further.

In early 2008 I conducted a small investigation of stand-up comedy in the UK to look for further lessons (Sturges, 2010). This was a satisfying exercise for someone like me who was already often attending comedy gigs, and in the process I had excellent cooperation from a number of comedians including two, Rhod Gilbert and Sarah Millican, who have since achieved star status. When it came to drawing conclusions from some nice, fresh data on how the comedians handled the possibility of giving offence, I probably rushed forward too fast so as to complete an article that I could offer for publication and reached what I would now consider rather weak and unimaginative conclusions. Amongst these was the suggestion that we could learn something from the handling by comedians of offended minorities. I took the suggestion of one comedian that if one or two people in an audience laughed, then the material was funny and need not be revised, and reversed it to look at one or two protesters. These protesters might form one or two percent of a club audience, but one or two percent of a TV audience or indeed the clientele of a library would scale up to thousands or tens of thousands.

From this I drew the conclusion that libraries needed to follow the example of most comedians who tacitly respected the mass or volume of the protest they created and considered adjusting their material accordingly. What I failed to draw out was something of which I was aware, which was that the response of most comedians was not to adjust the material but to remove it from their act or tone it down very considerably. They do this in the interests of future bookings from clubs, possible TV opportunities and eventual stardom. Only a few comedians resist protest and either defend their freedom of expression or choose to revel in causing offence. If librarians followed the example of comedians, the content of most libraries would be effectively censored and library contributions to freedom of expression would be of limited value. What I had done was to follow an easy interpretation of my findings, rather than saying straight out that, like librarians, comedians are threatened by protest and it requires courage or pig-headedness to stand out against. True, a call to be pigheaded does not sound like a sensible conclusion, but who says that all conclusions must be sensible? I do not, but sometimes I let 'being sensible' overpower my imagination, which is exactly what my advice to anyone reading this is to avoid. 


\section{Concluding remarks}

Finally, I admit that imagination cannot solve every research problem. What it can do is to move the researcher a few steps away from the conventional responses. If LIS were a fully functional discipline with successful and inspiring body of research, this might not be important. My original contention was that LIS research, taken as a whole (published, submitted for publication, or not actually intended for full publication), includes a preponderance of depressingly poor material. To break out of this there needs to be an emphasis on standards, but what is suggested here is that improved standards in the selection of topics, reading, thinking theoretically, selecting and using methods, and drawing strong conclusions from findings is only part of an answer. Imagination needs to be given flight in all of these areas, and LIS is a sufficiently open field that there is great scope for this to be productive and successful.

\section{References}

Amaratunga, C. and Shute, J. (1982) Extension and adult learning in a Ghanaian community, Canadian Journal of African Studies, 16, 549-566.

Habermas, J. (1991) The structural transformation of the public sphere. Cambridge, MA: MIT Press.

Ramachandran, V. (2004) A brief history of human consciousness: from impostor poodles to purple numbers. New York: Pi Press.

Rose, S. (2006) The twenty-first century brain: explaining, mending and manipulating the mind. London: Vintage.

Sturges, P. (2004) Information in the national liberation struggle: developing a model, Journal of Documentation, 60(4) 428-448.

Sturges, P. (2006) Limits to freedom of expression? Considerations arising from the Danish cartoons affair, IFLA Journal, 32(3) 181-188.

Sturges, P. (2008) Simple but effective LIS research: why we need it, and how we can do it, Library and Information Research 32(100) 29-34.

Sturges, P. (2010) Comedy as freedom of expression, Journal of Documentation 66(2), 279-293.

Sturges, P. and Chimseu, G (1996) The chain of information provision in the villages of Malawi: a rapid rural appraisal, International Information and Library Review, 28, 135-156.

Sturges, P. and Neill, R. (1998) The quiet struggle: information and libraries for the people of Africa. London: Mansell.

Winston, R. (2003) The human mind and how to make the most of it. London: Bantam Books. 


\section{Open access and copyright}

Library and Information Research is an open access journal. A freely available copy of this paper may be downloaded from the journal's website:

http://www.lirgjournal.org.uk/lir/ojs/index.php/lir

Copyright and associated moral rights in works published in Library and

Information Research are retained by the author(s) but this paper may be used freely, with proper attribution, in educational and other non-commercial settings. 